\title{
EFFECT OF CROPPING SYSTEM ON YIELD OF SOME SWEETPOTATO AND OKRA CULTIVARS IN AN INTERCROPPING SYSTEM
}

\author{
NJOKU S. C., A. O. ANO, L. E. F. AMANGBO, \\ A.O. AKINPELU AND C. N. EBENIRO \\ National Root Crops Research Institute, Umudike, \\ P. M. B 7006, Umuahia, Umuahia, Abia State, Nigeria
}

\begin{abstract}
A field trial was conducted for 2 years to determine cropping system effect on yield of some sweetpotato and okra cultivars in an intercropping system. Sweetpotato variety TIS 87/0087 produced significantly $(P<0.05)$ higher number of tubers per plant than Tis 8164 and Tis 2532.op.1.13 varieties. Tuber yield was also significant in 2000, but was not in 2001. Intercropping generally increased okra plant height while interaction of okra with sweetpotato and cropping system showed significant differences in pod length and pod width. The land equivalent ratio of sweetpotato and okra cultivar were all above 1.0 indicating that higher productivity per unit area was achieved by growing the two crops together than growing them separately.
\end{abstract}

Keywords: Sweetpotato, Okra, Intercropping, Land equivalent ratio

\section{INTRODUCTION}

Intercropping using improved varieties of crops and improved agronomic practices remain the most feasible approach to optimizing crop production and maximizing the use of available land (Adetunji, 1993). Okigbo and Greenland (1976) reported that intercropping was the dominant cropping system in West Africa and that farmers did not only aim at multiplying the net returns per unit area by growing extra crops; but making a better use of available space, and also maximizing the cost of production. Other advantages include soil protection, greater yield stability, variability of food supply, and insurance against crop failures (Beets, 1982).

The cultivation of sweet potato in Nigeria is now coming into prominence. Though, observation shows that it is extensively grown more in the Northern States than the Southern States. It has also been found to be available in varying quantities in the appropriate local markets all the year round (Arene, Ogbuehi and Chinaka, 1982).Intercropping sweet potato a high calorie food for its tuberous root as source of carbohydrate, vitamins and minerals, feed and agro industrial raw materials (Wolfe 1992), and a vegetable crop like okra with its tender fresh pod rich in mineral, vitamin, protein and oil, (Epenhuisen, 1974; Martin, 1982) ensure supply of dietary carbohydrate, vitamins and minerals of the rural populace.

The ecological problems like increasing urbanization, soil erosion and land fragmentation has decreased the amount of arable land available to the farmers (Chukwu et al 1996). Moreover, with the limited resources existing in the traditional farming operations, intercropping sweet potato and okra are expected to maximize the utilization of the scarce resources and thereby increase the farmer's income. Although okra has been intercropped with other vegetables, legumes and food crops, there is dearth of information on its intercropping with sweet potato. Combination of the two crops will encourage two cropping seasons on the same land since they are both short duration crops. 


\section{MATERIALS AND METHODS}

The study was conducted at National Root Crops Research Institute Umudike for two years. Umudike is located on lat $5^{\circ} 29^{\prime} \mathrm{N}$ and long $7^{\circ} 32^{\prime} \mathrm{E}$. The altitude is 122 meters above sea level. The soils are classified as typic paleudult derived from coastal plain sands (Chukwu and Ifenkwe, 1996). The soils are acidic and are deficient in $\mathrm{N}$ and $\mathrm{K}$. The top-soil $(0-20 \mathrm{~cm})$ texture of the experimental site is sandy loam. The experimental field was ploughed, harrowed and ridged using conventional tillage method. The experiment was a $3 \times 3$ factorial arrangement in a randomized complete block design (RCBD) with three replications. Three varieties of sweetpotato, TIS 87/0087, TIS 8164 and TIS 2532.OP.1.13 were intercropped with three varieties of okra, Nhae 47-4, Tae 38 and UM 38 giving nine treatment combinations. Sole components of each crop variety were included for comparison, and computation of land Equivalent Ratio (LER).

Sweetpotato vines measuring $20 \mathrm{~cm}$ in length with (4 nodes) were planted at the crest of ridges at the spacing of $1 \mathrm{~m} \times 0.3 \mathrm{~m}$ to give 33,000 plants per hectare. Three okra seeds were planted at a spacing of $1 \mathrm{~m} \times 0.5 \mathrm{~m}$ and later thinned to one plant per stand to give 20,000 plants per hectare. Weeding was done 3 weeks after planting with hoe. NPK 15:15:15 fertilizers were applied at the rate of $400 \mathrm{~kg}$ per hectare on one side of the ridge 4 weeks after planting. The second weeding was carried out 8 weeks after planting. No weeding was required after sweet potato full vegetative cover. Okra plant height was measured 6 weeks, and 8 weeks after planting (WAP). Harvesting of okra pods started 70 days after planting at an interval of every 4 days. Sweetpotato harvesting was done at 16 weeks after planting (WAP) when leaves turned yellowish, and vines starts drying which are signs of senescence and tuber maturity. The harvested tubers were weighed and recorded. At the end of the harvest data collected was subjected to analysis of variance (ANOVA) according to Steele and Torrie (1980) for a factorial experiment.

\section{RESULTS AND DISCUSSION}

The yield and number of tubers of sweet potato for the two copping seasons are shown in Table 1. From the result, in 2000 TIS $87 / 007$ had greater number of tuber [ $\mathrm{P}<0.05]$ than TIS 8164 and TIS 2532.op.1.13, and there was significant difference in the tuber yield among the three sweetpotato varieties but in 2001 TIS 87/0087 and 2532 OP1.13 each had higher tuber number [ $\mathrm{p}<0.05$ ] than TIS 8164 but the tuber yield was not significant.

Table 1: Effect of intercropping three sweet potato varieties with okra on mean yield of Sweetpotato roots.

\begin{tabular}{lllllll}
\hline Treatment & \multicolumn{2}{l}{ No of root per ha } & \multicolumn{4}{c}{ Root weight (t/ha) } \\
Sweet potato cultivars & $\mathbf{2 0 0 0}$ & $\mathbf{2 0 0 1}$ & Mean & $\mathbf{2 0 0 0}$ & $\mathbf{2 0 0 1}$ & Mean \\
\hline TIS 87/0087 & 2.90 & 2.63 & 2.77 & 23.87 & 16.03 & 19.95 \\
TIS 8164 & 2.18 & 1.96 & 2.07 & 24.39 & 15.57 & 19.98 \\
TIS 2532.op.1.13 & 2.29 & 2.41 & 2.35 & 15.87 & 16.67 & 16.27 \\
LSD & 0.28 & 0.39 & & 4.01 & NS & 3.03 \\
\hline
\end{tabular}

In both years significant difference was observed among the sweet potato varieties on number of tubers with TIS $87 / 0087$ having higher tuber number than the other varieties [Table 2]. TIS 87/0087 intercrop produced higher tuber number than TIS 2532.OP1.13 and TIS 8164 intercrop irrespective of Okra cultivar in 2000 and 2001. For tuber yield, the result for 2000 showed significant difference among the sweet potato varieties for sole and intercrop but was not for 2001. Interaction of cropping system and sweet potato varieties were not significant $[p>0.05]$ in some variables recorded. 
Journal of Agriculture and Social Research (JASR) VOL. 10, No. 2, 2010

Table 2: Effect of Cropping System on No of roots and root yield of Sweet potato Cultivars

\begin{tabular}{lcccc}
\hline Treatment & \multicolumn{2}{l}{ No of root per ha } & $\begin{array}{l}\text { Root } \\
\text { (t/ha) }\end{array}$ & weight \\
Sweet potato cultivars & $\mathbf{2 0 0 0}$ & $\mathbf{2 0 0 1}$ & $\mathbf{2 0 0 0}$ & $\mathbf{2 0 0 1}$ \\
\hline Sole TIS/87/0087 & 2.80 & 2.43 & 24.67 & 16.03 \\
Sole TIS 8164 & 2.20 & 1.90 & 30.38 & 14.10 \\
Sole TIS 2532.OP.1.13 & 2.17 & 2.30 & 15.33 & 16.60 \\
Intercrop Tis 87/0087 & 2.99 & 2.84 & 23.47 & 16.00 \\
Intercrop TIS 8164 & 2.15 & 2.02 & 17.93 & 17.06 \\
Intercrop TIS 2532.OP.1.13 & 2.41 & 2.52 & 16.40 & 16.93 \\
LSD & 0.39 & 0.54 & 6.08 & 4.29 \\
\hline
\end{tabular}

In sweet potato and Okra intercropping, TIS 87/0087 in combination with Nhae 47-4 or Um 38 in 2000 showed the highest number of tuber and TIS 8164 with Nhae 47-4 having the least tuber number (Table 3). And in 2001 TIS 87/0087 with um 38 had the highest number of tubers. This was in agreement with the report of Okwuowulu and Asiegbu [2000] and Okorie and Okpala [2000] on the superiority of TIS 87/0087.The interaction of cropping system and sweet potato varieties significantly affected total tuber number but not tuber weight. The presence of Okra did not significantly affect the tuber weight of any of the sweet potato varieties.

Table 3: Effect of Sweet potato $x$ Okra interaction on sweet potato root number and root yield.

\begin{tabular}{lllll}
\hline Sweet potato X okra & No of & roots & $\begin{array}{l}\text { root } \\
\text { (t/ha) }\end{array}$ & Weight \\
& $\mathbf{2 0 0 0}$ & $\mathbf{2 0 0 1}$ & $\mathbf{2 0 0 0}$ & $\mathbf{2 0 0 1}$ \\
\hline TIS 87/0087 X Nhae 47-4 & 3.30 & 2.07 & 25.00 & 17.10 \\
Tis 87/0087 X Tae 38 & 2.67 & 2.73 & 20.60 & 17.83 \\
Tis 87.0087 X Um 38 & 3.03 & 3.00 & 24.50 & 18.63 \\
Tis 8164 X Nhae 47-4 & 1.87 & 2.40 & 15.17 & 16.60 \\
Tis 8164 X Nhae 47-4 & 2.30 & 2.00 & 20.17 & 15.63 \\
Tis 8164 X Um 38 & 2.30 & 2.53 & 18.20 & 15.73 \\
Tis 2532.op.1.13 X Nhae 47-4 & 2.33 & 2.70 & 15.97 & 16.90 \\
Tis 2532.op.1.13 X Tae 38 & 2.80 & 2.57 & 17.43 & 14.63 \\
Tis 2532.op.1.13 X Um 38 & 2.13 & 2.93 & 16.00 & 16.33 \\
LSD & 0.49 & 0.87 & 6.57 & 3.21 \\
\hline
\end{tabular}

The effect of Okra and sweet potato intercrop on Okra plant height and days to $50 \%$ flowering are presented on Table 4 for 2000 and 2001 cropping seasons. Okra variety Nhae 47-4 was the tallest followed by Tae 38 and then by Um 38 in both years, and Nhae 47-4 took fewer days of 48-50 to attain 50\% flowering than the other varieties that takes between 60 to 65 days in both years. This was in agreement with the report of Orkwor [1990] and Ikeorgu et al, [1983] that the most important features of plant which determines their competitive ability for light is height. 
Journal of Agriculture and Social Research (JASR) VOL. 10, No. 2, 2010

Table 4: Effect of intercrop on okra plant height and days to $50 \%$ flowering in 2000 and 2001 cropping seasons

\begin{tabular}{lllll}
\hline Treatment & \multicolumn{3}{l}{ Plant height (cm) } & \multicolumn{2}{l}{ No of days to 50\% } \\
& \multicolumn{4}{c}{ flowering } \\
& $\mathbf{2 0 0 0}$ & $\mathbf{2 0 0 1}$ & $\mathbf{2 0 0 0}$ & $\mathbf{2 0 0 1}$ \\
\hline Okra X Sweet Potato & & & & \\
Nhae 47-4 & 83.55 & 59.42 & 48.18 & 46.17 \\
Tae 38 & 64.58 & 60.85 & 58.88 & 59.00 \\
UM 38 & 54.10 & 49.00 & 61.60 & 56.17 \\
L.S.D 0.05 & 4.01 & 3.15 & 2.77 & 3.49 \\
\hline
\end{tabular}

On average, intercropped Okra was similar in height but flowered earlier than the sole crop in 2000.In 2001, intercropped Okra was taller than the sole crop but both flowered at the same time as the difference in time of flowering was not significant [Table 5] Muoneke et al [1997] reported that the taller Okra plants obtained in intercrop with maize was a bid to display the leaves for interception of solar radiation. Olasantan and Lucas (1992) also noted that canopy height is one of the important features that determine competitive ability of plants for light.

Table 5: Cropping system effect on plant height and days to $50 \%$ flowering in 2000 and 2001

\begin{tabular}{lllll}
\hline Treatment & \multicolumn{3}{l}{ Plant height $\mathbf{( c m )}$} & \multicolumn{2}{l}{$\begin{array}{l}\text { No of days to 50\% } \\
\text { flowering }\end{array}$} \\
& $\mathbf{2 0 0 0}$ & $\mathbf{2 0 0 1}$ & $\mathbf{2 0 0 0}$ & $\mathbf{2 0 0 1}$ \\
\hline Cropping System x Okra Interaction & & & & \\
\hline Sole Nhae 47-4 & 85.33 & 78.23 & 50.00 & 47.67 \\
SoleTae 38 & 65.23 & 57.97 & 60.67 & 58.00 \\
Sole UM 38 & 53.00 & 47.97 & 65.33 & 54.33 \\
Intercrop Nhae 47-4 & 81.77 & 80.60 & 46.37 & 44.67 \\
Intercrop Tae 38 & 63.93 & 63.73 & 57.10 & 60.00 \\
Intercrop UM 38 & 55.20 & 50.17 & 57.87 & 58.00 \\
L.S.D 0.05 & 5.40 & 5.47 & 3.72 & 4.71 \\
\hline
\end{tabular}

Okra and Sweet potato interaction (table 6) In the interaction NHEA 47-4 with Tis 87/0087 gave the highest height while UM 38 with Tis $87 / 0087$ showed the least height in 2000 . In 2001 NHAE 47-4 with Tis 2532.0p1.13 gave the highest with the least height coming from UM 38 with Tis 2532.op.1.13. But the interaction between cropping system sweet potato and okra varieties did not influence okra height and days to $50 \%$ flowering in the varieties.

Table 6: Effect of okra $x$ sweetpotato interaction on okra plant height and days to 50\% flowering.

\begin{tabular}{|c|c|c|c|c|}
\hline \multirow[t]{2}{*}{ Treatment } & \multicolumn{2}{|c|}{ Plant height $(\mathrm{cm})$} & \multicolumn{2}{|c|}{$\begin{array}{l}\text { No of days to } 50 \% \\
\text { flowering }\end{array}$} \\
\hline & 2000 & 2001 & 2000 & 2001 \\
\hline \multicolumn{5}{|l|}{ Okra x Sweet potato Interaction } \\
\hline Nhae $47-4 \mathrm{x}$ Tis $87 / 0087$ & 87.40 & 81.73 & 81.73 & 47.33 \\
\hline Nhae $47-4$ x Tis 8164 & 76.60 & 75.90 & 45.00 & 47.33 \\
\hline Nhae $47-4 \mathrm{x}$ Tis 2532.op.1.13 & 84.13 & 84.13 & 46.67 & 43.67 \\
\hline Tae $38 \mathrm{x}$ Tis $87 / 0087$ & 63.80 & 63.43 & 60.00 & 61.67 \\
\hline Tae $38 \times$ Tis 8164 & 63.33 & 62.60 & 56.67 & 59.67 \\
\hline Tae $38 \mathrm{x}$ Tis 2532.op.1.13 & 64.70 & 65.13 & 55.67 & 58.67 \\
\hline
\end{tabular}


Journal of Agriculture and Social Research (JASR) VOL. 10, No. 2, 2010

\begin{tabular}{lllll}
\hline Um $38 \times$ Tis $87 / 0087$ & 53.83 & 53.57 & 58.67 & 58.67 \\
Um 38 x Tis 8164 & 55.47 & 49.77 & 57.33 & 56.67 \\
Um 38 x Tis 2532.1.13 & 56.63 & 47.17 & 57.67 & 59.33 \\
L.S.D 0.05 & 6.36 & 6.87 & 3.75 & 4.35 \\
\hline
\end{tabular}

For pod width and pod length (see Table 7.) The pod width was longer $(\mathrm{p}<0.05)$ in Nhae 47-4 than other varieties and this was significant, pod length on the other hand was the same for the three okra cultivars in 2000. But in 2001, pod width and pod length was highest in okra variety Nhae 47-4 than those of the other two varieties. With highest pod width and length occurring in Nhae 47-4 shows that it has a high potential attributes over the other cultivars.

Table 7: Cropping system $x$ okra interaction on pod width and pod length

\begin{tabular}{lcccc}
\hline Treatment & \multicolumn{2}{c}{ Pod width $(\mathrm{cm})$} & \multicolumn{2}{c}{ Pod length $(\mathrm{cm})$} \\
& 2000 & 2001 & 2000 & 2001 \\
\hline Okra x Sweet potato & 3.93 & 3.50 & 5.40 & 11.20 \\
\hline Sole Nhae 47-4 & 2.33 & 2.33 & 3.77 & 7.73 \\
Sole Tae 38 & 1.47 & 1.73 & 4.33 & 5.47 \\
Sole Um 38 & 3.17 & 3.77 & 3.80 & 6.03 \\
Intercrop Nhae47-4 & 2.00 & 2.10 & 4.57 & 4.33 \\
Intercrop Tae38 & 1.47 & 1.80 & 4.37 & 5.03 \\
Intercrop Um38 & 0.39 & 0.63 & 0.75 & 1.17 \\
L.S.D 0.05 & & & &
\end{tabular}

The effect of intercropping sweet potato and okra on pod width and length showed that intercropping increased pod width and length in 2000 and 2001, with Nhae47-4 and Tis87/0087 as having the highest in pod length and width (Table 8). While intercropping Tae 38 with Tis 8164 sweetpotato gave the least pod length and Um38 and Tis87/0087 with least pod width. Interaction of okra with sweet potato and cropping system showed significant $(\mathrm{p}<0.05)$ difference in both pod width and length.

Table 8: Effect of 0kra and Sweetpotato and their interactions on okra pod length and pod width.

\begin{tabular}{lcccc}
\hline Treatment & Pod Length $(\mathbf{c m})$ & & Pod Width $(\mathbf{c m})$ \\
& $\mathbf{2 0 0 0}$ & $\mathbf{2 0 0 1}$ & $\mathbf{2 0 0 0}$ & $\mathbf{2 0 0 1}$ \\
\hline Okra x Sweet potato & & & & \\
\hline Nhae 49-4x Tis 87/0087 & 3.53 & 7.60 & 3.73 & 4.03 \\
Nhae 47-4 xTis 8164 & 4.43 & 5.77 & 3.73 & 3.60 \\
Nhae 47-4xTis 2532.op.1.13 & 3.43 & 4.77 & 2.60 & 3.70 \\
Tae 38x Tis 87/0087 & 6.40 & 3.53 & 2.07 & 2.10 \\
Tae 38 xTis 8164 & 5.10 & 3.00 & 2.30 & 2.00
\end{tabular}


Journal of Agriculture and Social Research (JASR) VOL. 10, No. 2, 2010

\begin{tabular}{lcccccc} 
Tae $38 \times$ Tis 2532.op.1.13 & 2.20 & 6.43 & 1.40 & 2.20 & & \\
Um 38 x Tis 87/0087 & 4.40 & 6.43 & 1.37 & 1.53 & & \\
Um 38 x Tis 8164 & 4.77 & 4.00 & 1.50 & 2.07 & & \\
Um 38 x Tis 2532.1.13 & 3.97 & 4.73 & 1.50 & 1.77 & LSD & 0.05 \\
& 0.81 & 1.06 & 0.49 & 0.78 & & \\
\hline
\end{tabular}

The effect of cropping system on number of pods per plant and fresh pod yield of okra varieties are shown in Table 9. There were significant $(\mathrm{P}<0.05)$ differences between the sole and intercrop okra yields. Considering number of pods per plant in both years sole cropped out yielded the intercropped with Nhae 47-4 having the highest number of pods of 8.37 and 8.53 for both years.

Fresh pod yield for 2 years showed significant $(\mathrm{P}<0.05)$ difference among the different okra yields. In 2000 the highest pod yield was recorded in sole UM38 with a yield of 3.93t/ha while in 2001 sole Nhae $47-4$ recorded the highest pod yield of 4.30 t/ha. The pods yield differed from one variety to another and were significantly influenced by the cropping system. The presence of sweet potato a planophile did not depress okra fresh pod yield but improves the yield of companion crops probably by conserved soil moisture and reducing high noon temperature thereby making the micro environment more conducive for growth and development. This report agrees with the work done by Ikeorgu 1984 in a melon intercrop.

Table 9: Cropping system effect on yield of okra in sweet potato and okra Intercrop

\begin{tabular}{llclc}
\hline Treatment & \multicolumn{2}{c}{ No of pods per plant } & \multicolumn{2}{c}{ Fresh pod yield (kg) } \\
& $\mathbf{2 0 0 0}$ & $\mathbf{2 0 0 1}$ & $\mathbf{2 0 0 0}$ & $\mathbf{2 0 0 1}$ \\
\hline Okra x sweet potato & & & & \\
\hline Sole NHae 47-4 & 8.37 & 8.53 & 3.30 & 4.30 \\
Sole Tae 38 & 8.20 & 8.17 & 2.63 & 3.10 \\
Sole Um 38 & 8.27 & 7.00 & 3.93 & 3.63 \\
Nhae 47-4 x Tis 87/0087 & 5.13 & 5.90 & 2.07 & 3.10 \\
Nhae 47-4 x Tis 8164 & 7.13 & 3.90 & 3.53 & 4.57 \\
Nhae 47-4 x Tis 2532.op.1.13 & 5.40 & 7.30 & 3.43 & 3.80 \\
Tae 38 x Tis 87/0087 & 7.13 & 7.27 & 3.23 & 3.43 \\
Tae 38 x Tis 8164 & 7.30 & 3.20 & 3.47 & 3.20 \\
Tis 38 x Tis 2432.op.1.13 & 8.07 & 5.93 & 2.80 & 3.17 \\
Um 38 x Tis 87/0087 & 5.03 & 8.27 & 3.43 & 3.07 \\
Um 38 x Tis 8164 & 3.80 & 3.00 & 3.50 & 3.47 \\
Um 38 x Tis 2532.op.1.13 & 5.70 & 3.77 & 3.73 & 2.83 \\
LSD & 3.96 & 2.55 & 1.35 & 1.29 \\
\hline
\end{tabular}

The total land equivalent ratio (LER) for 2000 and 2001.

In 2000 the LER of the mixed crops ranged from 1.9 to 3.1 while in 2001, the LER range from 1.8 to 2.2 (Table 10). The sweet potato and okra mixtures were all above 1.0 indicating that higher productivity per unit area was achieved by growing the two crops together than by growing them separately As a measure of the efficiency of a cropping system, any mixed system that has LER of more than 1.00 is said to be more efficient than the sole crop. .

The highest yield advantage for the two cropping season of 2.6 was obtained by intercropping Nhae 47-4 with Tis 2532.op.1.13 sweet potato or Tae 38 okra with Tis 87/0087 sweet potato. This confirms similar result obtained by Muoneke and Asiegbu (1997) in okra 
cowpea mixture. The superior LER obtained by the intercropping made the mixture a more productive option and agree with earlier reports of Pinchinat, et al (1976) who had recommended crop mixtures yielding LER of 1.39 to 1.63 as being good mixtures.

Table 10: Total land equivalent ratio (LER) of sweet potato and okra intercrops in 2000 and 2001

\begin{tabular}{llll}
\hline Sweet potato x okra cultivars & $\mathbf{2 0 0 0}$ & $\mathbf{2 0 0 1}$ & Mean \\
\hline Sole Nhae 47-4 & 1.0 & 1.0 & 1.0 \\
Sole Tae 38 & 1.0 & 1.0 & 1.0 \\
Sole Um 38 & 1.0 & 1.0 & 1.0 \\
Sole Tis 87/0087 & 1.0 & 1.0 & 1.0 \\
Sole 8164 & 1.0 & 1.0 & 1.0 \\
Sole Tis 2532.op.1.13 & 1.0 & 1.0 & 1.0 \\
Nhae 47-4 x Tis 87/0087 & 1.9 & 1.8 & 1.85 \\
Nhae 47-4 x Tis 8164 & 2.6 & 2.2 & 2.40 \\
Nhae 47-4 x Tis 2532.op.1.13 & 3.1 & 2.0 & 2.55 \\
Tae 38 x Tis 87/0087 & 2.9 & 2.2 & 2.55 \\
Tae 38 x Tis 8164 & 2.6 & 2.2 & 2.40 \\
Tae 38 x Tis 2532.op.1.13 & 2.7 & 1.9 & 2.30 \\
Um 38 x Tis 87/0087 & 2.6 & 2.0 & 2.30 \\
Um 38 x Tis 8164 & 2.2 & 2.1 & 2.35 \\
Um 38 x Tis 2532.op.1.13 & 2.7 & 2.0 & 2.35 \\
\hline
\end{tabular}

\section{CONCLUSION}

In the two year intercropping studies to determine compatibility of three sweet potato cultivars Tis 87/0087, Tis 8164 and Tis 2532 of 1.13 with three cultivars of okra N-hae 47-4, Tae 38 and Um38 showed that the yields from the three sweet potato cultivars were significant (p0.05) under sole and mixed cropping. Tis $87 / 0087$ significantly $(\mathrm{P}<0.05)$ out yielded Tis 8164 and Tis 2532 of 1.13 with regards to number and yield of tubers ,Pod length, width, pod number and fresh pod yield.

For optimum yield advantage, sweet potato variety Tis 87/0087 and Tis 2532.Op.1.13 can be combined with okra variety Tae 38 and Nhae 47-4 respectively as these mixtures gave the highest LER of 2.6, on average. In both years, superior LER with not less than 1.9 and some as high as 2.6 was recorded. Result therefore showed that sweet potato and okra are compatible crops that could be used in intercrop.

\section{REFERENCES}

Adetunji, A.I. (1993). Growth and yield of intercropping (sorghum bicolar) and sunflower (helianthus annus L). in Semi arid, Nigeria. Journal of Agronomy and crop science. $171: 351-357$.

Beet, W.C. (1982) Multiple cropping and tropical farming systems west view press Inc. Baulder Colorado, 8030 USA.

Chukwu, G.O. and Ifenkwe G.E. (1996). An edaphological approach to biodiversity Conservation in Ikwuano Local Government Area of Abia State: Implications for agro technology transfer proceedings. $5^{\text {th }}$ Annual conference of Nigerian society for biological conservation, Umudike pp $91-94$.

Epenhuijsen, C.V. van (1974). Growing native vegetables in Nigeria, FAO Publications, Rome.University of Ibadan, April, 1984.

Ikeorgu, J. E.G.(1984). Some micro environmental changes under cassava maize intercrops grown with okra and egusi a PhD Thesis University of Ibadan, April, 1984. 
Martin, F.W. (1982). Okra potential multipurpose crop for temperate zones and the tropic, Economic botany: 36 (3) 340-345.s.

Muoneke, C.O., J.E. Asiegbu and A.C.C. Udeogalanya (1997). Effect of relative sowing time on the growth and yield of the component crops in okra/maize and okra/cowpea intercropping systems. Journal of Agronomy and Crop Science 179(3):179-185.

Okorie, P.E. and E. Okpala (2000). Effect of animal manure and inorganic fertilization on ground flora development sites in Umudike, Nigeria. Journal of sustainable Agriculture and the environment. 1(2).

Okwuowulu, P.A. and J.E. Asiegbu (2000). Optimum of K-fertilization and harvest age of four sweet potato (Ipomoea batatas L Lam) varieties for food tuber yield in a tropical Utisol. Nigeria Agricultural Journal. 31: 67-77.

Olasantan, F.O. and E.O. Lucas (1992). Intercropping maize within crops of differing canopy heights and similar or different maturities using different spatial arrangements. Journal of Agriculture Science and Technology, 1.2 (1): 13-15.

Orkwor, G.C. (1990). Studies on the critical period of weed interference in yam (Dioscorea rotundata poir) intercropped with maize (zea mays) okra (Abelmoschus esculentus L. moenech) sweet potato and the biology of associated weeds $\mathrm{PhD}$ thesis, University of Nigeria Nsukka.

Pinchinat, A.M: Soria and R. Bazau (1976). Multiple cropping in tropical America, P. 51-61. In: R.I. Papendick, P.A. Sanchez and G.B. Triplett (eds). Multiple cropping, A.S.A. Special Publications, No. 27, Madison, WISC.

Steele, G.D. and J.H. Torrie (1980). Principles and procedures of statistics. A biometrical approach. $2^{\text {nd }}$ edition. McGraw-Hill book company Inc. New Year. 633pp.

Wolfe, J.A. (1992). Sweet potato an untapped food resource publications in Collaboration with CIP, Peru, Cambridge University Press. 